\title{
EU wrangles internally over safety of donated tissues and cells
}

The EU's three legislative bodies are struggling to agree on a directive on safety of donated human tissues and cells for medicinal use. The Council of Ministers wants companies to abide by the new rules, which were drafted by the European Commission (EC), which according to industry would stifle innovation. At the same time, the European Parliament (EP) demands the inclusion of a ban on all human cloning. Yet if all cannot agree for the EP's vote by mid-December, the whole directive could end up being shelved.

For years, biotech companies have been begging the European Union for clear regulation on the use of donated human tissues and cells for medical products-a sector expected to flourish in coming years. The wider use of donor cells for medical treatments introduces health risks, comparable to contamination of blood products by HIV in the 1980s. These risks prompted the European Commission (EC; Brussels) to produce a draft for the Directive on Quality and Safety Standards for Human Tissue and Cells (2002/0128). "This has been one of the few times industry has asked for more government regulation," says Heidi de Wit, associate director for corporate affairs at Genzyme Europe (Brussels).

The only current EU rules on human cell or tissue-based products are laid down in a directive that governs market approval of all medicinal products $(2003 / 63)$ under a section called 'somatic cell therapy.' Although this rule covers cell therapies, the directive is not clear concerning more innovative cell therapies developed recently.

Because of this lack of EU rules, getting new products to the European market is a "nightmare," says Shayesteh Fürst-Ladani, manager of global regulatory affairs at Baxter Bioscience (Vienna). Baxter had trouble getting its fibrin sealant, consisting of cultured skin cells spread out on a matrix for application to wounds, approved throughout Europe in 1999 and faces more hurdles with products in its pipeline. Bumping into similar barriers is Genzyme, a global biotech working on cartilage replacement products and genetically modified stem cells to restore heart muscle mass and function after bypass surgery.

And it's not just the headaches from a patchwork of regulations that could keep treatments from reaching the market, says Erik Tambuyzer, Genzyme Europe's senior vicepresident for corporate affairs. He adds that the current absence of a European stamp of approval discourages third-party reimbursement of such treatments, preventing a new

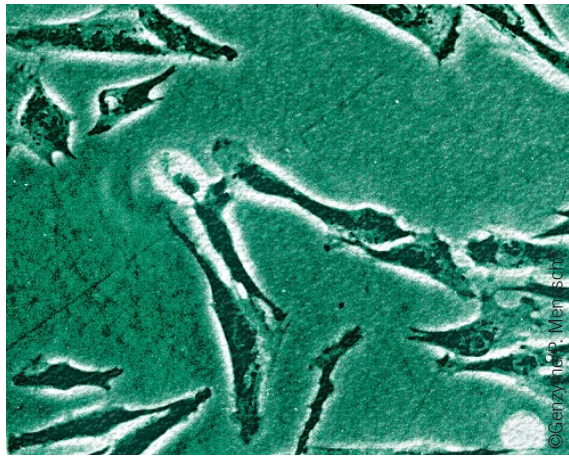

Cell therapies, such as these used to strengthen weakened hearts, lack sufficient regulation in Europe.

market sector from growing.

Because of EU procedures, the EC, the EP and the Council must agree on the rules or there will be no new directive at all. The three bodies currently agree on proposed guidelines for the creation of "accredited tissue banks" that will dispense samples to academic and industrial researchers, but they do not agree on additions such as the EP's ethical provisions nor on the EC's proposals on how to regulate marketed tissue and cell-based products (see Box 1).

The biotech industry, however, would prefer no add-ons to the directive at all. Consumer and public health rules for industrial products, as proposed by the Council, would create more immediate problems, says Fürst-Ladani, because many companies would have a hard time getting accredited as official "tissue establishments," thus giving a de facto monopoly to publicly funded traditional tissue banks. Moreover, says Tambuyzer, the directive lacks essential market provisions, such as assessment of product safety and efficacy, protection of intellectual property and sensitive clinical data, and a clear definition of a company's liability in case something goes wrong.

In addition, the industry would not be satisfied if the EP sticks to ethics provisions that would hinder research. A Europe-wide ban on therapeutic human cloning, furthermore, would hardly qualify as a rule "sufficiently broad as to allow scientific and medical research to accommodate the developments [of cell therapies]...over the next few years," as asked for by an October 2003 position paper published by the European Bioindustry Association (EuropaBio, Brussels) titled 'Human stem cell research: a novel technology that will benefit patients.'

A second and final EP vote is scheduled for December 15 and last-minute negotiations between the EP, the EC and the Council are now in full swing. With ongoing closed-door deliberations and key provisions still up in the air, biotech lobbyists are left wondering what to wish for: having unfavorable EU regulation or having no regulation at all. But some still hope for a happy ending. "I think all parties will find a common position," says Fürst-Ladani. "If not, it will be politically disadvantageous for all of them."

Peter Vermij, Washington

\section{Box 1 Timeline of EU human cell and tissue Directive}

Partly in response to industry's wishes, the EC Directorate General for Health and Consumer Protection (known as Sanco in French-speaking Brussels) in 2002 drafted minimum quality and safety standards for human tissues and cells. To protect both tissue donors and receivers, Sanco proposed that only "accredited tissue banks" should be allowed to obtain and screen donated tissues and cells, narrowly guided by its provisions. This draft consitutes the basis of the 2002/0128 Directive.

The debate heated up when the EP, in its first reading in March 2003, demanded a host of ethical provisions, including a ban on the use of cloned human embryos and a prohibition on payments for human body parts. 'Safety and ethics cannot be separated,' says Peter Liese, Parliament's rapporteur on the matter, responding to critics who say EU treaties do not allow for safety rules to be used as a way of imposing ethical boundaries on member states. (Currently several countries, including the UK and Sweden, would allow the future use of cloned human embryos to treat disease.)

The Council of Health Ministers, strongly rejected Parliament's ethical additions in May 2003 and added some ideas of its own. Instead of just regulating the handling of source materials and transplants, it wanted Sanco to also cover industrial manufacturing and distribution of derived products, as long as no good market regulation for such products is in place - a situation that could easily last several years. 